\begin{tabular}{lcl}
\hline \multicolumn{1}{c}{ A N N A L E S } \\
UNiversitatis & MARIAE CURIE-SKŁODOWSKA \\
LUBLIN - POLONIA & \\
VOL. XXI, 1 & SECTIO K & 2014 \\
\hline
\end{tabular}

Maria Curie-Skłodowska University, Lublin, Poland

ARTUR BŁAŻEJCZYK

\title{
Determinants of Poland's Endeavors for the Accession to the North Atlantic Treaty Organization
}

\begin{abstract}
Analysis of the consequences of power balance disturbance in the Central-Eastern Europe after the dissolution of the Warsaw Pact and regaining sovereignty by states remaining under the dominance of the Union of Socialist Soviet Republics after World War II leads to recognizing Poland's accession to NATO as Poland's indisputable diplomatic success providing it with a new instrument serving to implement its raison d'état and strengthen its independence. The membership determines the long-range perspective of Poland's perception as a stable state on the international stage.
\end{abstract}

Key words: Central-Eastern Europe, international relations, NATO, Poland

\section{INTRODUCTION}

After the demise of communism in Central-Western Europe and the transformation of the Cold War's bipolarity into multipolarity, the decrease of predictability of the turbulent international environment gradually became obvious. This situation affected particularly the European continent, the political-military architecture of which had been disrupted. Due to the increase of multilateralism, an outstanding and prominent place in stabilization of the polyarchic world that we face at the beginning of the $21^{\text {st }}$ century, is occupied by the North Atlantic Alliance. 
The purpose of this article is to answer the question concerning the advantage of benefits resulting from the accession of the Republic of Poland to the North Atlantic Treaty Organization over losses caused by it. In order to do so, the article presents multidimensionally the groundwork of the NATO's enlargement on the background of a wider process of formerly communist Central-European states' integration with Euro-Atlantic structures.

The reason for choosing this subject by me is the particular interest that I - as an International Relations graduate - take in broadly defined issues of international security and defense matters as well as their position in contemporary geopolitical questions in a global context and the very transatlantic relations.

I shall present the reasons and circumstances of recognizing the integration with NATO structures as one of Polish foreign policy of the 1990s' priorities, divided into determinants able to be referred to as historical, geopolitical and military ones, and supplemented by opportunities and threats linked to accession perspectives.

\section{HISTORICAL DETERMINANTS}

The Polish state - together with its nation and army - used to give proof of its commitment to the values of the civilization of the West for numerous times throughout the history. Under the call 'For freedom yours and ours' Poles participated repeatedly in struggle for freedom and justice: defending Europe at Vienna, fighting for the independence of the USA and under Napoleon Bonaparte's banners; building (after the November Uprising) the army of the independent Belgium. During the World War I times they battled on all its fronts; in 1920, only 2 years after regaining independence, the Polish soldier participated in the struggle with the Bolsheviks (as it was defined by Lord d'Abernon - in the $18^{\text {th }}$ deciding battle in the world history) [Leszkowicz 2009]. During the interwar years Poland - related with the United Kingdom and France by an alliance - represented an integral part of the democratic Europe. In World War II period the government-in-exile of the Republic of Poland never resigned itself to the loss of independence. The Land, Maritime and Air Polish Armed Forces, within a coalition with the Allies, struggled on all the fronts: from Narvik to Tobruk, from the sky above London to Monte Cassino. After the end of the war Poland remained fenced off from the western civilization by the 'Iron Curtain' for long decades against the Poles' will [Jemioło 1997: 5].

The acts of military services and wars abound in changes of hitherto alliances, therefore the change of the alliance affiliation of the Polish Armed Forces should have been a relatively simple process; however, it has not. Firstly, the contemporary alliances (more precisely - NATO) are organizations with structures already so formed that the formula of a simple accession, known from the past, has virtually become an objectless issue. Secondly, there exist justifiable doubts whether the Warsaw Pact was an alliance at all. In May of 1955 the representatives of the USSR submitted to 
the summoned delegations of the European communist stated a document that, after less than an hour, was accepted without any essential discussion or correction. In such manner there was created the Pact that was registered in the UN as a defensive alliance. In reality, Poland could not make sovereign decisions regarding its future because the command, coordination of all activities, plans of the use of the armies and all other strategic decisions were controlled by the Soviet General Staff. During the whole existence of the Warsaw Pact the post of the Commander-in-Chief was wielded by the vice-Minister of Defence of the USSR [Balcerowicz 1997: 64].

The operational units of the Polish Armed Forces were to constitute a reliable nexus within the Pact's alliance of socialistic 'brotherly armies' [Podsiadło 2009], which prejudged not only the ideology but also the structures, equipment and dislocation of the army, which means also its character and purpose. The Polish army received clearly expressed tasks in operations planned for the Western Theatre of Warfare, and to be precise - on the Northern Seaside and Jutland Operational Directions [Piotrowski 2009]. Only to these objectives have all the organizational and training activities been subordinated even in the time of peace. After the eventual mobilization the Polish Army was to be regrouped to the "output area" of Mecklenburg and proceed further by exercising the truculent operation preceded by the phase of shielding the construction of the striking cluster. It can be stated that the Polish army was well prepared to fulfill concrete tasks on a concrete area, in a concrete war and alongside with concrete allies. No alternate conditions, areas of activity or models of war were considered possible. At the end of the Warsaw Pact's existence the Polish Armed Forces counted over 400 thousand soldiers, over 2,800 tanks, 2,400 transporters and infantry fighting vehicles, over 2,300 canons and over 500 airplanes [Balcerowicz 1997: 65, 67]. Its armament and equipment may be assessed as relatively modern, although placing themselves below NATO standards.

As a matter of fact, the Warsaw Pact began to resemble a real alliance only in July of 1990, when in the closing declaration of the session of the Political Advisory Committee in Moscow there appeared a postulate of "(...) transformation of the Warsaw Pact into a system of sovereign and equal states" [Balcerowicz 1997: 64], which may be considered today as a historical curiosity.

Lasting for half a century, the dependence from the USSR and functioning within the structure of the Warsaw Pact have left in the Polish army a distinct and deep mental decline, difficult to be overcome. Poland has faced an entirely new reality not only with an 'old' defensive system, an 'old' army, but also with whole the ballast of a truculent, coalitional doctrine and military thought linked with a system of concepts and intellectual constructions demanding a profound verification if not abandonment. It turned out to be a necessity to get rid of stereotypes ingrained for decades, e.g. the enemy's image and the model of a future war as an armed clash of coalitions ideologically hostile to each other. 
The new situation required thinking of defense without indicating an enemy, based on multilateral analysis of challenges, threats and security problems [Balcerowicz 1997: 68].

After the dissolution of the Warsaw Pact, Poland found itself in a group of 'shadow zone' states which neither were members of any alliance nor were constituting any themselves but also did not decide about their neutrality or disengagement. At the turn of the 1980s and 1990s the newly emerging European and world order was not very clear. There came into existence a necessity if redefining the challenges, threats, risk factors and visions of possible armed conflicts in Europe. A model of a war on a large scale, conducted by two powerful blocs, remaining in force for almost half a century, became objectless due to a sudden lack of a clearly defined foe. For the staff planners, it was a shocking situation, because in every military doctrine the identification of the enemy and specification of the expected conflict's character is the starting point. First reactions were limited to the attempt of indicating at least the directions of threats [Balcerowicz 1997: 65-67]. The unpredictability of processes occurring in the decaying USSR, and the simultaneous presence of Soviet (and later - Russian) troops withdrawing from the territory of Germany indicated 2 such directions: Western and Eastern ones. In search of a reasonable formula, there was even temporarily adopted a postulate of 'defence at all azimuths' (a quotation from the Minister of Defense's speech [Szumski \& Wągrowska 2009].

The year 1989 brought about the end of the Europe's division into opposite parts. In the years 1990-1993 there appeared new states - their number increased from three to seven. Although it was only in 1991 that the Warsaw Pact and the USSR ceased to exist, the pro-Western orientation of the noncommunist cabinet appointed after the election in June of 1989, was legible since the very beginning. The project matured finally in 1992, which was reflected in the doctrinal document "Security Policy and Defensive Strategy of the Republic of Poland" [Jemioło 1997: 5-6]. The Membership in NATO was written therein as a strategic goal. All major political forces' full consent to that Project appeared after the parliamentary election in 1993 [Jemioło 1997: 5-6].

First post-Solidarity cabinets initiated the great Polish effort crowned with full success and a historic sign of the end of the previous century - admission of Poland, together with the Czech Republic and Hungary, to the North Atlantic Treaty Organization on March 12, 1999. As the Polish honorary legitimation in it there can be acknowledged examples of bloodshed incurred in the past jointly with American, British, French, Canadian and other soldiers.

\section{GEOPOLITICAL DETERMINANTS}

In 1990s the leaders of the Polish state used to include in the thinking of its security both the opportunities for its ensuring and increasing, and the threats for 
it. There can be issued an assumption, that there was taking place (in a level higher than so far) a striving for using - in the first place - the chances that were created by the foreseen development of the international situation in the world and in Europe. Undoubtedly, one of such was a tendency to create a European element of transatlantic security system. In the vital interest of Poland there was vested supporting pursuits in that direction, initially mainly by enlargement of the role of the OSCE (Organization for Security and Co-operation in Europe), and later - also by widening of structures of the Western European Union and NATO - the strongest transatlantic organization in the security field [Koziej 1996: 6].

After the dissolution of the Warsaw Pact and later - USSR, there appeared a question fundamental for NATO, concerning the sense of its further existence. Alongside with the loss of the enemy the alliance was left without its main task - the necessity of common defense. Neorealists, inter alia Kenneth N. Waltz, predicted therefore an imminent decay of NATO: "NATO's days are not numbered, but years are... NATO is a vanishing creation. The question is, how much longer it will remain a significant organization, even if its fame may still last for a long time" [Waltz 1993: 75].

From the time perspective it can be assumed that in new reality the concern for NATO's survival turned out to be unjustified as much as the anxiety for its cohesiveness, significance and effectiveness. NATO has remained active and vivacious, and - without giving up its previous assumptions - began to widen and expand its action field. There is a lot of reasons for NATO's survival: firstly - the need for a strong organization possessing an appropriate executive branch, an organization that would be reliable in the security system shaping after the Cold War period. Secondly - the NATO's members' consent for its further existence, based on an unshakeable conviction about benefits resulting from that fact, supported by the concrete new states' will of accessing the Pact. Thirdly - the values of this organization: a potential greater than needed to fulfill only military functions; developed mechanisms of dispute resolution, consultations, multipurpose co-operation and coordination of foreign and military policies; efficiency; high level of institutionalization; appreciation and authority among the international community. Since NATO is an alliance with constantly deepening internal integration, what tends to undergo betterment is the allies' processes of consultation and security policy's coordination, as well as - in staff dimension - planning, schooling, procedure improvement, creation of multinational structures etc. [Balcerowicz 1997: 86-87].

At the beginning of the 1990s, NATO faced a necessity of redefining its identity and adapting to the definitely changed environment with new challenges and threats. Its catalogue is described by the Strategic Concept [Dziubdziela 2009]. Only in its first sentence is it underlined that they - faced by NATO - are of a clearly different character than in past because the menace of a simultaneous full-scale attack on Europe was removed and in Central Europe the risk of an unexpected attack severely decreased. Moreover, according to the Concept, the risk for the allied states' security has now a multidimensional and multidirectional character, and the threats 
are difficult to predict and assess. A deliberate aggression against the allies' territory is unlikely; the threat will rather be a result of destabilization caused by serious economic problems, social and political difficulties, together with ethnical rivalry and territorial disputes (Central-Eastern Europe was recognized as particularly exposed to these problems). Changes taking place in the USSR were perceived on the background of its conventional and nuclear military potential. Among the "challenges and threats' there were mentioned the areas of the Mediterranean Sea and Middle East. It was considered to be necessary to comply the global context of the security threats - both those according to which there would be applied the articles 5 and 6 of the Washington Treaty and those of a wider character alike (e.g. mass destruction weapons' proliferation, terrorism and sabotage) [Dziubdziela 2009] [Koncepcja Strategiczna NATO 1991] [Traktat Pótnocnoatlantycki 1949].

New elements in the NATO Concept - in particular concerning activity outside the responsibility area and crisis management policy - indirectly influenced also Poland's defensive concepts, even before its accession to NATO. As a means of strengthening Poland's defense there was seen the extension of the Alliance's reach of its stabilizing influence to Poland (together with a bigger area of its geographic neighborhood), which would diminish the shadow security zone, and yet reduction of threats in Europe means shrinkage of conflict and war risk (obviously, no one considered appearing of such a fact as widening the threat range). It was expected that the enlarged NATO will collaborate even more effectively with other international security organizations and institutions (particularly UN and OSCE) [Koziej 1996: 6].

\section{MILITARY DETERMINANTS}

After 1989, in the Polish Army there has come a time of unprecedented - comparing to the military conditions - animation of theoretical thought, acute discussions and opinion clashes because against completely new challenges of the already sovereign Poland there remained not only the 'old' defense system and 'old' army but also the whole ballast of truculent, coalitional doctrine and military thought - a system of ideas and mental constructs requiring a thorough verification and - in a lot of cases - even rejection. What needed getting rid of was the stereotypes deeply ingrained for decades - the foe's image and the future war's model. There were commonly noticed the effects of another stereotype, namely - the conviction that defense is a 'worse', forced kind of combat activities. There were considered such issues as: assessment of defensive needs (including mainly military threats), strategic and operational concepts of resisting those threats and ways of preparing the defensive system (mainly armed forces) to the implementation of doctrinal concepts.

Polish defensive (in effect: warlike) doctrine had been so far a derivative of the Soviet one dominated by a model assuming adversative coalitions' armed clash. New situation required thinking of defense without indicating an enemy but resulting from 
multilateral analysis of challenges, threats, risks and security problems. What was not a subject of change was the regularity whereby the military factor on the one hand deters a potential aggressor, and on the other - documents its own defensive value on the international stage [Balcerowicz 1997: 66-69].

A recognized and widely used, and recently considered the best, method of achieving the requisite security level by a state is entering into alliances (coalitions, pacts, blocs) [Balcerowicz 1997: 63]. Various sources define an alliance among others as "historically oldest form of organization of the international stage and states' cooperation" [Stefanowicz 1996: 109], “a covenant of international meaning, consisting of undertaking co-operation in the field of politics, military service and mutual help in given situations" [Jarosz \& the team 2004] and (according to R. Vukadinović) "an agreement of connection of efforts of two or more states with the aim of strengthening each one's defensive force against an armed assault from outside or in order to prepare an aggression against a third state" [Vukadinović 1980: 274].

Poland's membership in alliance - de facto in NATO - became its security's option practically without alternatives at the beginning of the 1990s. As Polish defensive policy's strategic objective, it was written down in two doctrinal documents adopted in November of 1992 by the President of the Republic of Poland and Country Defense Committee: in "Assumptions of Polish Security Policy" [Bartoszewski 2009] and "Security and Defensive Strategy of the Republic of Poland" [Polityka Zagraniczna RP. Opracowanie 2009], however obtaining all major political forces' unanimity in this regard took place after the parliamentary election in 1993. Both documents designated the strategic direction towards integration with western security structures, alongside ensuring friendly relations with all the neighbors, taking into account the then conditions of Poland's defensive autonomy. As it was revealed later, they constituted an announcement of adjustment of Polish concepts and defensive system, including mainly the operational armed forces, to NATO's requirements and standards. It meant that there were mattered the limitations of latitude of forming by Poland its defense and there was expected a willingness to undergo the common rigors and demands concerning both strategic thinking and the composition, structure and doctrinal procedures of preparing the defensive potential. It was not forgotten that keeping an internationally reliable military potential represents a necessary condition of the country's security [Koziej 1996: 5] [Założenia Polskiej Polityki Bezpieczeństwa 1992] [Polityka bezpieczeństwa i strategia obronna Rzeczypospolitej Polskiej 1992].

In the 1990s it was expected that what would dominate the widened NATO's strategy, would be the issues of widely understood crisis management, i.e. preventing crises and solving them. Membership in the Alliance's perspective and possible wider share in structures of multinational military formations and missions in areas distant from Poland's territory did indeed cause a necessity of expanding the field of Polish strategic concern, monitoring system and crisis events' assessment. In the first place it was necessary to build and develop the crisis response system that would be compatible with NATO's - forces of high battle readiness level, mobile and versatile, able 
to act in various conditions together with other NATO states' armies. The Alliance, as an organization fulfilling crisis response tasks with the UN or OSCE mandate, could in future demand that Poland engages in arguments with states indifferent to its interests so far. Such interventions could result for the Republic of Poland in threats of economic nature or retaliation actions performed by one of the sides of the conflict in extinguishing of which Poland would engage [Koziej 1996: 9].

New strategic environment, challenges and security threats' analysis based on Article 15 of the Strategic Concept from 1991 leads to the following conclusion: changed conditions change neither the Alliance's aims nor functions, whereas create for it new possibilities of defining its strategy under a wide approach to the security problem. The main means of implementation of the security policy continues to be keeping a military potential sufficient to prevent a war and ensuring effective defense to every threatened region (within the Alliance's territory) through enlarging the ability to constitute and elastically strengthen a multinational presence wherever and whenever there appears such a need. Article 21 lists the Alliance's fundamental tasks:

1. Ensuring, as one of necessary bases for stable conditions of security in Europe (...) a state in which no state is able to frighten or exert pressure (...) by threatening to use force.

2. Serving as a transatlantic forum for allies' consultations.

3. Fulfilling functions of deterring any form of aggression and defending against attack on any member state's territory.

4. Keeping strategic balance in Europe. In the Strategic Concept there can be found a confirmation of a purely defensive character of the Alliance's strategy. It is stated that "no possessed weapon will ever be used for the purposes different than self-defense". After the adoption of the new strategy, the previous 'elastic response' doctrine and "extended defense strategy" complementary thereto, were put an end to and replaced with a 'reduced extended military presence strategy' understood first of all as presence of indispensable elements of reconnoitering, command and control systems, infrastructure, logistics and troops in number necessary to ensure the ability of reacting in situation requiring it.

Implementing its new strategy, as early as December of 1991 the Defense Planning Committee has reviewed the armed forces' structure in accordance with guidelines, according to which the Alliance's forces were to be a sum of the following components: response forces (in 7\%), main forces (in 65\%) and reinforcement forces (in 28\%) [Balcerowicz 1997: 83-85].

In 1990s, there were 3 possible, impartial (independent even from particular states' political will) sources of potential warlike threats for Poland. They can be ranged by character and increasing probability as follows:

1. A multiscale, general war whose object Poland could become even irrespective of its will and which would be assuredly reaching whole country's territory since the very beginning. In such case, it should be necessary to achieve abandonment of the aggression and the enemy's withdrawal from Poland's territory through full 
developing of the defensive system and executing a strategic defensive campaign including regular and irregular activities of the operational troops and territorial defense. In case of defeat in the regular campaign there should be launched underground state's structures and common, armed and non-armed resistance against the occupant.

2. A local, objective- and scale-limited armed conflict during which direct, land, armed activities would reach a part of Poland's territory, while air and missile strikes, and rally, landing and diversionary actions could be performed on the whole country's territory too. What could repulse the aggression quickly, might be partial or total developing of the defensive system and carrying out a defensive-truculent operation or campaign in the attacked part of the country, with providing aircraft, anti-diversionary and other protection to the whole Poland's territory. As a part of withstanding threats of such a kind, the armed forces should be able to perform an autonomous campaign or operation leading to the fast defeating of the invasive enemy grouping and its expulsion from Poland's territory, as well as thwarting the enemy's renewed armed aggression in the short time.

3. A political-military crisis in Poland's less or more distant surroundings, that could procure mainly indirect threats (without signs of a direct armed action): terror acts, increase of organized delinquency, tides of civilian and military refugees, radioactive and chemical contamination, epidemics, armed bands' excursions, temporary violations of border by the struggling sides' combat groupings etc. (indirect threats may be linked with Poland's prospective participation - as a part of international forces - in armed conflicts performed far from its territory). Polish effort would be aimed at exclusion of developing the crisis into an aggression directly against the Republic of Poland thanks to active participation in armed and non-armed international efforts in favor of solving this crisis (crisis management) and strengthening the military and non-military defense of the country's territory against the conflict's indirect effects. In such case the armed forces' main tasks might consist of implementing undertakings of strategic alert (e.g. selective enhancing the combat readiness, reinforcing the country's borders' protection etc.) and secreting of groupings of varied composition and size in order to act within international groupings [Koziej 1996: 7-8, 11-12].

Amongst the Euro-Atlantic allies, Poland could became an equal partner only by contributing to NATO the former's own potential of a democratic state's defense, a state economically developed, politically stable, featuring an efficient and quite modern army allowing, in case of occurrence of a local or general and direct aggression, leading for at least some time military operations on its own, until the whole needed defensive potential of NATO is launched; this requirement was included in defensive planning and programming - the operational doctrine in Poland underwent a significant evolution: there stopped being implied big, massive clashes within coalitional truculent-defensive operations and began - maneuver operations with the dominant role of the information factor combined with territorial forces' irregular activities against the enemy, led rearwards [Koziej 1996: 12-14]. 


\section{CONCLUSIONS}

Transformations of Poland's geopolitical environment in the late 1980s/early 1990s not only brought an essential change to its social-political-economic system but also changed significantly the way in which Polish society and political class perceive broadly seen security and defense issues. From the perspective of time, the several decade-long history of NATO's existence debunks the myth that this organization replaces member states' decision-making centers; it rather constitutes an important forum of consultations and intergovernmental arrangements targeting the best possible serving the member states' common interests.

As a member of NATO, Poland has received for its disposal a wide range of roles to which it may aspire to: among others, it may use the membership as a protective shield hedging its social-economic development, participate in enterprises in favor of peace-keeping, strive for obtaining the role of the main stabilizer of the area of the Central-Eastern Europe, try to become a 'bridge builder' between NATO and Eastern Europe or recognize the Pact as a means of obtaining full acceptance in the Western family of nations. In reality, there would probably appear a combination of the options mentioned above.

Basing on the practice of Polish activities within NATO performed so far, the main interests of the Republic of Poland may be considered as follows: keeping the Alliance's ability to execute collective self-defense according to the Article 5 of the North Atlantic Treaty, saving the geographical balance in the Alliance's activities in the age of its global engagement and balancing Polish participation in NATO and in the European Union's security policy. These objectives are strictly linked to each other.

Two latest decades of NATO's functioning differed from the first four in an essential way - in 1990s its members ceased to fear an external attack and focused on strengthening stability on the European continent. Belonging to the Pact in such form brings Poland a benefit not only as a means of deterring potential aggressors but also decisively improves the view of the Republic of Poland as a responsible and predictable participant of the international relations.

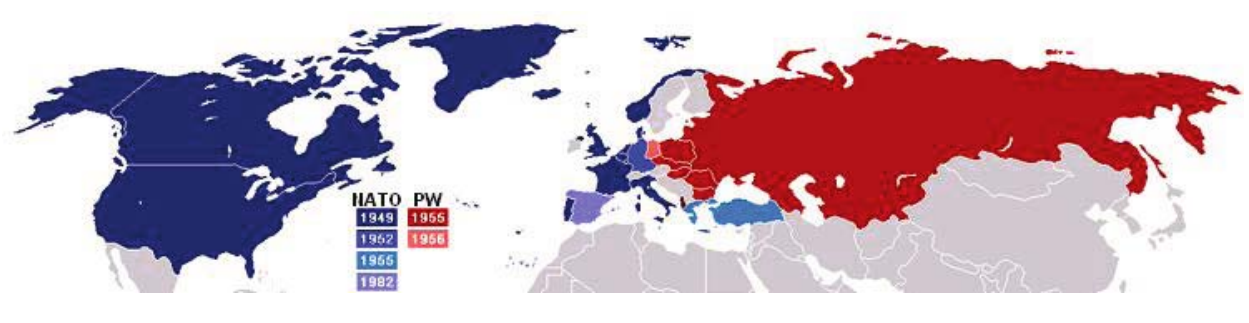

1. NATO and Warsaw Pact Member States

Retrieved from http://de.academic.ru/dic.nsf/dewiki/735939. 


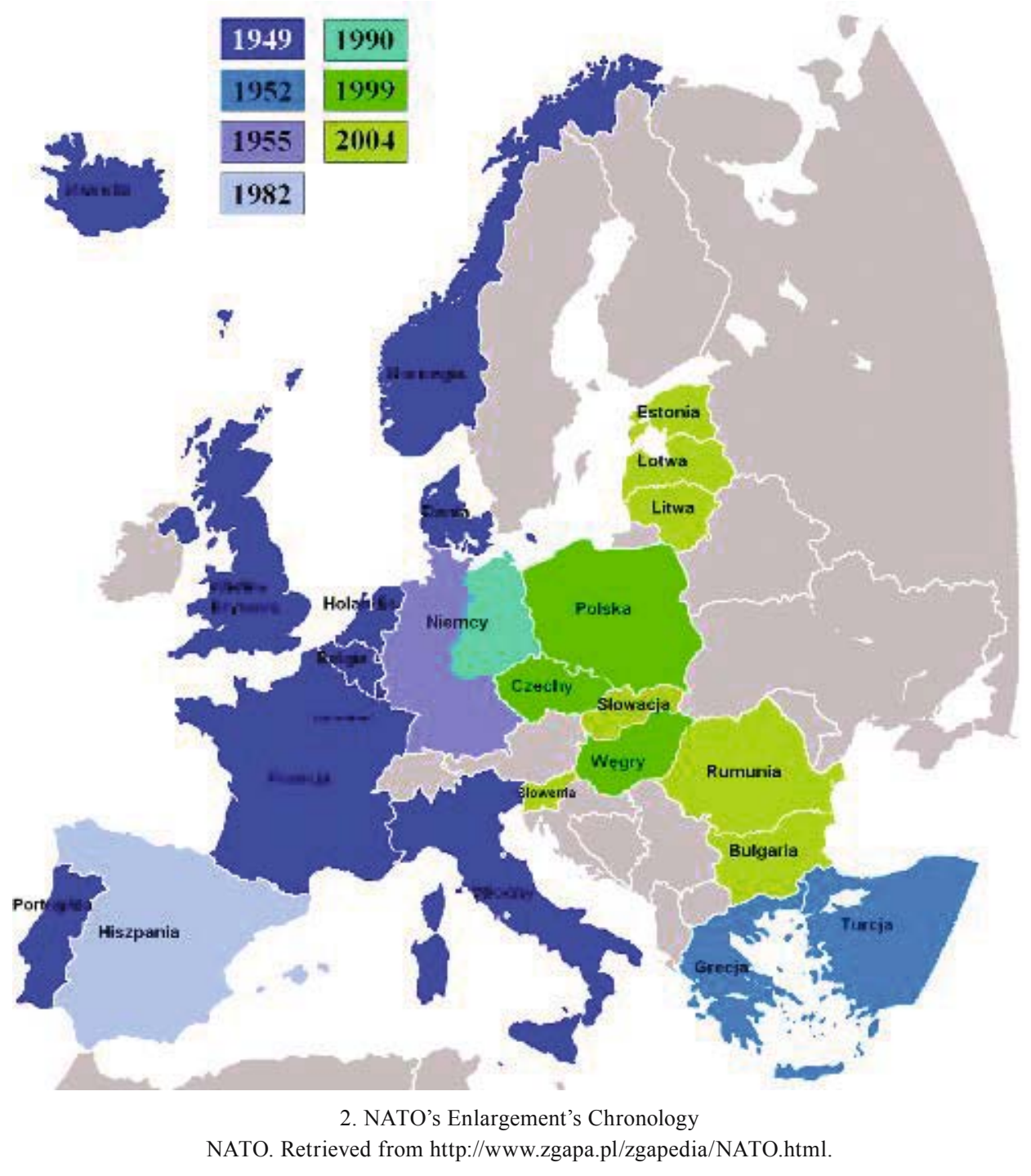




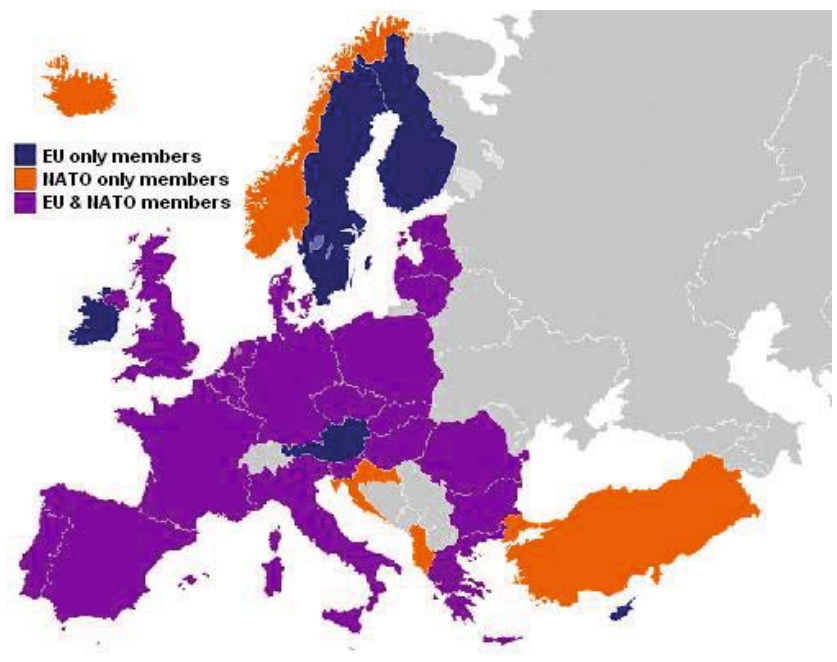

3. EU and NATO Members in 2010

North Atlantic Treaty Organization. Retrieved from http:/www.answers.com/topic/nato.

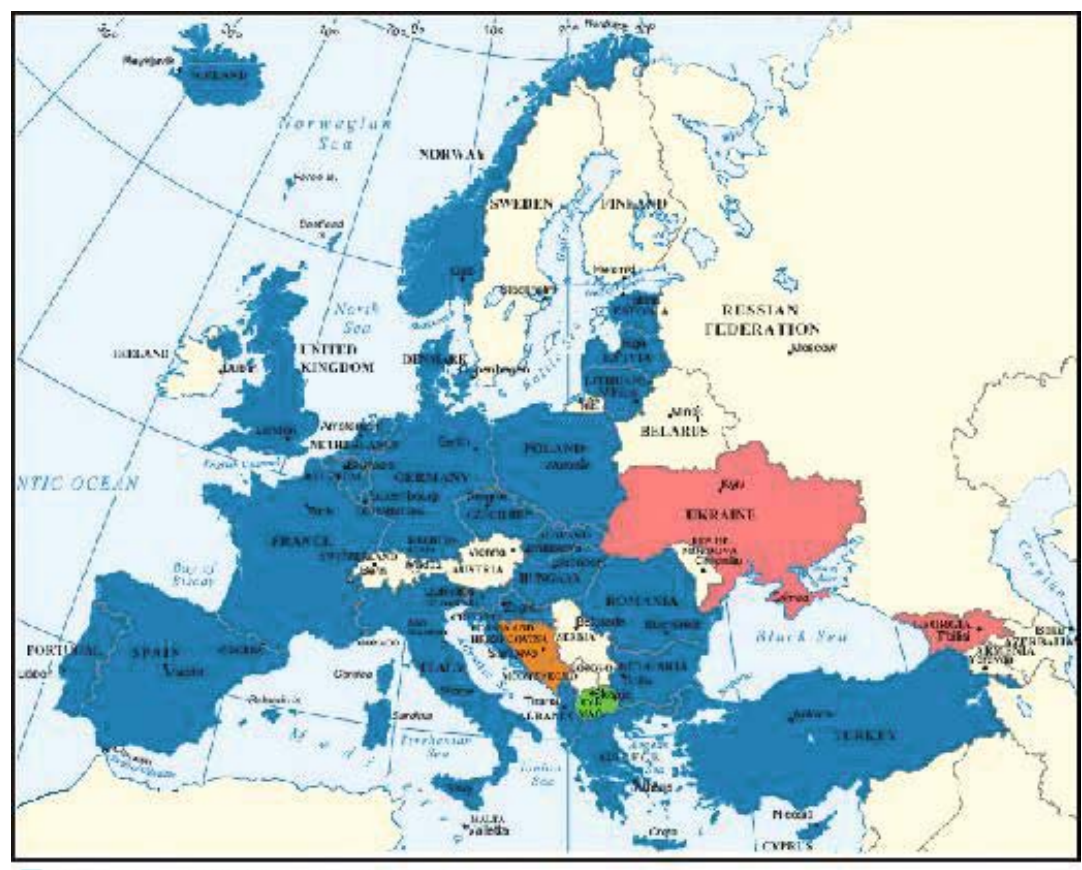

HATO members (plus USA \& Canada)

Membership Action Plan members

Intensified Dialogue states with annual national programmes

Intensified Dialogue States

4. NATO Members and affiliations in 2010

NATO enlargement Figure 2: NATO members and partners.

Retrieved from http://www.publications.parliament.uk/pa/cm200809/cms elect/cmdfence/276/27607.htm. 


\section{BIBLIOGRAPHY}

\section{SOURCES}

LEGAL ACTS

North Atlantic Treaty done at Washington on April 4, 1949. Retrieved from http://www.nato.int/cps/ en/natolive/official_texts_17120.htm.

\section{DOCUMENTS}

Koncepcja Strategiczna NATO done at Rome on November 7-8, 1991. Retrieved from http://www. nato.int/cps/en/natolive/official_te xts_23847.htm.

Polityka bezpieczeństwa i strategia obronna Rzeczypospolitej Polskiej done at Warsaw on November 2, 1992. Retrieved from http://www.koz iej.pl/files/Strategia_RP_z_92_r.doc.

Polityka zagraniczna RP. Opracowanie. Retrieved from http://www.adrenaline.rembertow.net/Polityka_Zagraniczna_RP_opracowanie.doc.

Założenia Polskiej Polityki Bezpieczeństwa done at Warsaw on November 2, 1992. Retrieved from http://www.koziej.pl/files/Strat egia_RP_z_92_r.doc.

\section{BOOKS}

Koziej, S. 1996. Polska doktryna obronna i jej modyfikacja w obliczu integracji z NATO, MONDBM, Warszawa.

Stefanowicz, J. 1996. Ład międzynarodowy, Instytut Studiów Politycznych PAN, Warszawa.

Vukadinović, R. 1980. Międzynarodowe stosunki polityczne, PWN, Warszawa.

\section{SELECTIONS FROM EDITED COLLECTIONS}

Balcerowicz, B. 1997. Od Układu Warszawskiego do NATO, [in:] Pod wspólnymi sztandarami. Droga Polski do NATO, A. Ajnenkiel (ed.), Akademia Obrony Narodowej, Warszawa.

Jarosz, M. \& the team 2004. Sojusz, [in:] Wielka Encyklopedia Świata, I. Kamińska-Szmaj (ed.), Oxford Educational, Oxford.

Jemioło, T. 1997. Stowo wstęne, [in:] Pod wspólnymi sztandarami. Droga Polski do NATO, A. Ajnenkiel (ed.), Akademia Obrony Narodowej, Warszawa.

\section{MAGAZINE ARTICLES}

Waltz, K. 1993. The Emerging Structure of International Politics, “International Security” no 2, p. 75. 


\section{DOCUMENTS OBTAINED FROM THE INTERNET}

Bartoszewski, W. Europejska polityka bezpieczeństwa. Polski punkt widzenia. Retrieved from http://www.cie.gov.pl/futurum.nsf/0/D7DE DE952177A774C1256CAB002B7F34 (reading date: 01.06.2009 r.)

Dziubdziela, A. Koncepcje strategiczne NATO. Retrieved from http://www.psz.pl/tekst-20937/AnnaDziubdziela-Koncepcje-strategiczne-NATO (reading date: 01.06.2009 r.)

Leszkowicz, T. 18. decydująca bitwa w dziejach świata. A co z pozostałymi siedemnastoma? Retrieved from http://www.histmag.or $\mathrm{g} /$ ?id=3285 (reading date: $01.06 .2009 \mathrm{r}$.)

Piotrowski, P. Desant na Danię. Retrieved from http://www.wprost.pl/ar/13287/Desant-na-Danie (reading date: 01.06.2009 r.)

Podsiadło, R. Sytuacja w Krakowie przed wyzwoleniem. Retrieved from http://www.dobroni.pl/ rekonstrukcje,sytuacja-w-krakowie-przed-wyzwoleniem,3308 (reading date: 01.06 .2009 r.)

Szumski, H. \& Wągrowska, M. Pokój na wszystkich azymutach. Retrieved from http://www.new-arch. rp.pl/artykul/151788_Pokoj_na_wszystkich_azymutach (reading date: 01.06.2009 r.)

\section{BIOGRAPHY}

Artur Blażejczyk: 24, has got a Master's degree in International Relations (specialties: European Integration and International Projects) and Bachelor's degree in Finance and Accounting (specialty: Banking and Accountance), both at Maria Curie-Skłodowska University in Lublin (UMCS), Poland. Currently, his prepares to get Master's degree in Finance and Accounting (specialty: Banking) at Warsaw School of Life Sciences (SGGW), Poland. His previous publication is an article entitled "Bill Clinton's Administration's Policy towards People's Republic of China" (written in Polish) published in UMCS Faculty of Political Sciences' CONSENSUS Student Research Bulletin (no 5/2011). His e-mail address is arturblazejczyk@o2.pl. 